\title{
THE ANALYSIS OF HUMAN ERROR AS CAUSES IN THE MAINTENANCE OF MACHINES: A CASE STUDY IN MINING COMPANIES
}

\author{
S. Kovacevic ${ }^{1}$, L. Papic ${ }^{2}$, G.L. Janackovic ${ }^{3^{*}}$ \& S. Savic ${ }^{3}$
}

\section{ARTICLE INFO}

\section{Article details}

Submitted by authors 17 Feb 2016 Accepted for publication 31 Aug 2016 Available online 6 Dec 2016

Contact details

* Corresponding author goran.janackovic@znrfak.ni.ac.rs

Author affiliations

1 JP PK Kosovo Obilic, Belgrade, Serbia

2 Faculty of Technical Sciences in Cacak, University of Kragujevac, Kragujevac, Serbia

3 University Of Nis, Faculty of Occupational Safety, Serbia

\section{ABSTRACT}

This paper describes the two-step method used to analyse the factors and aspects influencing human error during the maintenance of mining machines. The first step is the cause-effect analysis, supported by brainstorming, where five factors and 21 aspects are identified. During the second step, the group fuzzy analytic hierarchy process is used to rank the identified factors and aspects. A case study is done on mining companies in Serbia. The key aspects are ranked according to an analysis that included experts who assess risks in mining companies (a maintenance engineer, a technologist, an ergonomist, a psychologist, and an organisational scientist). Failure to follow technical maintenance instructions, poor organisation of the training process, inadequate diagnostic equipment, and a lack of understanding of the work process are identified as the most important causes of human error.

\section{OPSOMMING}

'n Twee-stap metode om die faktore en aspekte wat menslike foute gedurende die instandhouding van mynmasjinerie beïnvloed, word beskryf. Die eerste stap is die oorsaak-gevolg analise, wat met ' $n$ dinkskrum ondersteun word, waartydens vyf faktore en een-entwintig aspekte identifiseer word. Tydens die tweede stap word die groep-wasigheid-hiërargie analise proses gebruik om die geïdentifiseerde faktore en aspekte te rangskik. ' $n$ Gevallestudie is op mynondernemings in Serwië geloods. Die sleutelaspekte is rangskik volgens ' $n$ analise wat mynonderneming risiko kenners ('n instandhoudingsingenieur, 'n tegnoloog, 'n ergonoom, 'n sielkundige en 'n organisatoriese wetenskaplike) ingesluit het. Nalating om tegniese instandhoudingsinstruksies te volg, swak organisasie van die opleidingsproses, onvoldoende diagnostiese toerusting en ' $n$ tekort aan die verstaan van die werksprosesse is geïdentifiseer as die belangrikste oorsake van menslike foute.

\section{INTRODUCTION}

Every human-made product has a limited working life. Therefore, maintenance activities are important to achieve the necessary reliability of human-made products and complex production systems. The complexity of maintenance in modern mining systems is based on the combination and use of various resources and the characteristics of the dynamic environment in which they exist. Maintenance is usually categorised into preventive, corrective, and predictive types [1]. Maintenance extends the working life of machines, thus improving the cost efficiency of the system. The inspection and evaluation of machines' failure frequency can help to avoid large accidents $[2,3]$.

Due to the complexity of the production system, the organisation of the maintenance in coal mines is very important. Efficient maintenance can significantly increase efficiency, effectiveness, and the useful life of machines. The importance of maintenance in complex systems is emphasised by many authors $[1,4,5]$. In their work, Dhillon and Liu [1] classified human error into six categories: operating errors, assembly errors, design errors, inspection errors, installation errors, and maintenance errors. 
Maintenance errors occur due to inadequate, incorrect, or infrequent actions of maintenance personnel. Cause-effect analysis of human error with the highest risk degree during the performance of mining machines' maintenance operations enables the division of the main causes (cause of the first level) into less significant causes [6]. Furthermore, this analysis enables the visual presentation of revealed causes and an overview of their inter-connection.

Human factors during maintenance are important to consider because they relate to improved work performance and to the improved health, safety, and well-being of the workforce and the community [5]. Fewer accidents cause less stress and increase motivation for work.

When analysing human error, different factors and aspects have been identified: psychology and perception [7,8], training programmes [9-11], reliability analysis of the equipment [4], safety rules and regulations [12], organisation of maintenance [13], working conditions [14,15], working hours [16], and mining-machine maintainability [17]. Special programmes devoted to the safety and technical training of mining plant workers can also be useful for achieving higher levels of safety and for reducing errors during coal-mine work activities [18]. During the analysis, existing plant equipment, supplies, materials, and facilities, as well as plant talents and expertise, must be taken into consideration.

This paper describes the structure of the causes of human error in the maintenance of coal-mining machines in the Kosovo Obilic Company. A multi-criteria decision analysis method, based on the fuzzy analytic hierarchy process (AHP) [19], is applied in order to rank and determine the significance of key causes of maintenance errors.

\section{METHOD}

The method for identifying errors during the maintenance of coal-mining machines consists of two steps. The first step is conducting a cause-effect analysis, which should be supported by brainstorming. During the brainstorming session, experts define the factors (the causes of the first level) and aspects (the causes of the second level) affecting the existence of human error during maintenance operations. These causes are represented graphically by the Ishikawa diagram. The second step is the application of the group fuzzy AHP method to determine the significance of the identified key causes of human error.

\subsection{Analysis of human error during the maintenance of mining machines using cause-effect diagrams}

The cause-effect diagram, or fishbone diagram, is a simple technique for presenting and analysing causes and consequences; based on the principle of simple causality, this diagram helps to determine the causes of the problem [20]. The cause-effect diagram is a method of analysis that can help to establish which effects result from certain causes [6]. The causes are usually identified, based on the basic dimensions in production (the 8 ' $M$ 's): manpower, methods, machines, materials, measurements, milieu, management, and maintenance. The general presentation of this method, which will be used in the subject analysis of the problem of mining machines maintenance in this paper, is shown in Figure 1.

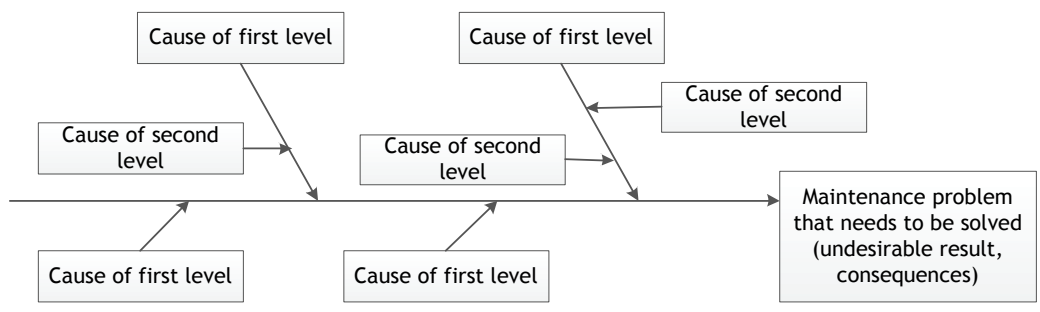

Figure 1: General scheme of maintenance problem analysis, adapted to the analysis of causes of mining machines maintenance problems [6]

The cause-effect diagram will be used in this paper to detect and systematise factors (causes) that affect the performance results during the mining machines' maintenance operation; i.e., sources that cause the maintenance problem. The main goal of this qualitative analysis is to identify the preventive measures on the basis of which corrective action could be undertaken to eliminate the 
problems of mining-machine maintenance, after their detection [6]. In that way, the cause-effect diagram is an effective tool to identify the corrective and preventive measures that need to be performed. It should be a mandatory procedure within the integrated management system in the organisation.

In this study, the causes of human error were initially analysed using a team that carried out a brainstorming process. The team acts in accordance with all the recommendations for brainstorming, as set out by the organisation $[21,22]$. The main recommendations are concerned with team composition, the working mode of the team, and the role of the team leader. The team generates ideas about the causes of the maintenance problem that need to be resolved. The general cause-effect diagram includes the categories of possible causes of some undesirable consequences of the maintenance process [6]. In this study, the analysis revealed the factors (causes) affecting the undesirable result or consequence: human error with the highest degree of risk when performing mining-machine maintenance operations.

Papic et al. [6] identified five main causes of undesirable events: lack of training, inappropriate information, lack of experience, carelessness, and neglect of danger (Figure 2).

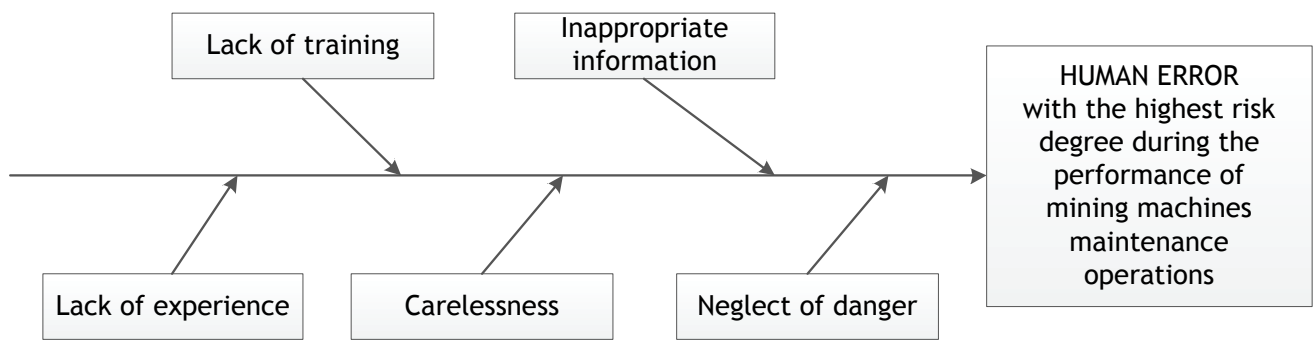

Figure 2: Potential causes of human error with the highest degree of risk during the performance of mining machines maintenance operations, in the form of the cause-effect diagram [6]

The analyses performed for this study have shown which types and causes of human error have the highest degree of risk during the performance of the corresponding maintenance operations of various mining machines, such as the bucket wheel excavator, landfill machine, dumping machine, self-transporter bandwagon, and the dragline dredge. These results are shown in Table 1 below and represented in Figure 2 above.

Since five main factors (causes of human error of the first level) are revealed in the subject analysis, as shown in Table 2, they are examined in more detail for the first-level causes; this leads to the investigation of causes of human error of the second and higher levels, as shown in Kovacevic [23].

In the chapter of Papic et al. [6], each assumption about the influential factors or causes affecting the analysed human factors problems in mining machine maintenance was presented in a particular location on the cause-effect diagram. That location was proposed by the author of the idea, and the decisions were made by the majority of the team members during the brainstorming process.

In our study, the team members discussed each cause-effect diagram after its completion, together and with the specialists who were not the team members, but employees of the open mine pits in the Kosovo Obilic Company. The employees provided questions and proposals that were discussed afterwards. In this way, and based on the literature review $[1,5,7,9,10,24]$, we identified the key causes of human error (Table 2 ). 
Table 1: Recapitulation of the types and causes of human error that have the highest degree of risk during performance of corresponding maintenance operations of various types of mining machines [6]

\begin{tabular}{lll}
\hline \multicolumn{1}{c}{$\begin{array}{c}\text { Type of mining } \\
\text { machines }\end{array}$} & \multicolumn{1}{c}{ Type of maintenance operation } & \multicolumn{1}{c}{$\begin{array}{c}\text { Potential causes of } \\
\text { human error }\end{array}$} \\
\hline $\begin{array}{l}\text { Bucket wheel } \\
\text { excavator }\end{array}$ & $\begin{array}{l}\text { Lifting operation of the upper rotational construction } \\
\text { and control of ball bearing. } \\
\text { Relaxation operation of upper rotational construction } \\
\text { with a support. } \\
\text { Replacement operation of steel rope for the working } \\
\text { bridge lifting/lowering. } \\
\text { Dismantling operation of spherical bearings on working } \\
\text { bridge incarceration. }\end{array}$ & Lack of training \\
& $\begin{array}{l}\text { Dismantling (assembly) operation of radial-axial ball } \\
\text { information }\end{array}$ & Lack of experience \\
bearing. & Carelessness \\
$\begin{array}{l}\text { Ramplang machine } \\
\text { Self-transporter } \\
\text { bandwagon }\end{array}$ & Lifting operation of self-transporter bandwagon. & Neglect of danger \\
Dragline dredge & Operation of cabin lifting and dragging. & \\
\hline
\end{tabular}

Table 2: The factors and key aspects of the proposed model, and their symbols

\begin{tabular}{ll}
\hline Symbols & Factors and aspects \\
\hline$a$ & Lack of training \\
$a_{1}$ & Poor training curricula \\
$a_{2}$ & Inadequate trainers \\
$a_{3}$ & Personal characteristics of the trainees \\
$a_{4}$ & Poor organisation of the training process \\
$b$ & Inadequate information \\
$b_{1}$ & Lack of guidelines \\
$b_{2}$ & Incomplete guidelines \\
$b_{3}$ & Inadequate diagnostic equipment \\
$b_{4}$ & Ambiguous guidelines \\
& \\
$c_{1}$ & Lack of experience \\
$c_{1}$ & Inadequate previous experience \\
$c_{2}$ & Insufficient years of service \\
$c_{3}$ & Application of inappropriate devices \\
$c_{4}$ & Low quality of commissioning and adjustment activities \\
$d_{1}$ & Carelessness \\
$d_{1}$ & Poor working conditions \\
$d_{2}$ & Living conditions \\
$d_{3}$ & Low motivation \\
$d_{4}$ & Personal characteristics \\
$e_{2}$ & Neglect of danger \\
$e_{1}$ & Poor organisation of the workplace \\
$e_{2}$ & Failure to follow technical maintenance instructions \\
$e_{3}$ & Lack of understanding of the work process \\
$e_{4}$ & Personal characteristics - risk propensity \\
$e_{5}$ & Inadequate instructions on work hazards \\
\hline &
\end{tabular}

\subsection{Determining the significance of the causes of human error during the maintenance of mining machines using fuzzy AHP method}

The results of the first step of the analysis of the causes of human error in coal mine machine maintenance are the factors (the causes of the first level) and the key aspects (the causes of the second level). The ranking of the key aspects is based on the group fuzzy AHP.

The fuzzy AHP method presents the problem in a hierarchical form, with the top level in the hierarchy presenting the goal, intermediate levels presenting the corresponding factors, and the lowest levels presenting the aspects or indicators. 
The pairs of elements at each level are compared for their relative influence on the elements at the hierarchical level above. Fuzzification and the pairwise comparison are implemented by the application of triangular fuzzy numbers. Triangular fuzzy numbers are described by the continuous linear membership function $\mu(x)$, and used during the pairwise comparison of the alternatives [25]. A fuzzy number is denoted as $M=(l, m, u)$, where $l \leq m \leq u, l$ and $u$ are the lower and the upper value of the support of $M$ respectively, and $m$ is the mean value [19].

The scale used during the comparison is shown in Table 3. A fuzzy distance $\delta=2$ is used for odd values, and $\delta=1$ for even values.

Table 3: The scale used for ranking the factors and aspects

\begin{tabular}{lll}
\hline Crisp value (x) & Judgement description & Fuzzy values \\
\hline 1 & Equally important & $(1,1,3)$ \\
3 & Weak dominance & $(1,3,5)$ \\
5 & Strong dominance & $(3,5,7)$ \\
7 & Demonstrated dominance & $(5,7,9)$ \\
9 & Absolute dominance & $(7,9,9)$ \\
$2,4,6,8$ & Intermediate values & $(x-1, x, x+1)$ \\
\hline
\end{tabular}

The final weights are derived through the aggregation of the weights at two consecutive levels, where factors are compared with respect to the goal, and the aspects are compared with respect to each of the factors. The elements of the fuzzy aggregate pair-wise comparison matrix are calculated as the geometric mean of individual grades of experts. Let $A^{(k)}=\left(a_{i j}{ }^{(k)}\right)_{n \times n}$ be the fuzzy judgement matrix of the $k$-th expert, where $a_{i j}>0, a_{i j}=1 / a_{j i}, a_{i j}=1$, and $n$ is the number of criteria or indicators to be compared.

The individual weights are calculated by means of the row geometric mean method (RGMM), which is defined by Crawford and Williams [26]. The aggregated fuzzy judgement matrix for the criteria and aspects is calculated based on the individual fuzzy judgement matrices:

$$
\tilde{a}_{i j}=\prod_{k=1}^{m}\left(\tilde{a}_{i j}{ }^{(k)}\right),
$$

where $A^{(k)}$ is the judgement matrix of the $k$-th decision-maker, and $m$ is the number of decisionmakers. Based on the elements of fuzzy aggregated matrix, the fuzzy weight is calculated as follows:

$$
\mathbf{w}_{j}=\left(w_{L j}, w_{M j}, w_{U j}\right)=\frac{\left(\prod_{l=1}^{n} \tilde{a}_{i l}\right)^{1 / n}}{\sum_{i=1}^{n}\left(\prod_{l=1}^{n} \tilde{a}_{i l}\right)^{1 / n}},
$$

where $j=1, \ldots, n$, and $n$ is the number of different criteria or alternatives that are compared in pairs.

Crisp weights are obtained from fuzzy weight by calculation of the mean value:

$$
w_{j}=\left(w_{L j}+w_{M j}+w_{U j}\right) / 3 \text {. }
$$

The final ranking of alternatives is based on the mean aggregated weight (MAW):

$$
w_{j}^{*}=\frac{w_{j}}{\sum_{k=1}^{n} w_{k}} \text {, }
$$

where $j=1, \ldots, n$, and $n$ is the number of weights of the criteria or aspects compared in pairs. In order to assess the consistency of the obtained results, the centric consistency index $(\mathrm{CCl})$ is used [19]:

$$
C C I(A)=\frac{2}{(n-1) \cdot(n-2)} \sum_{i<j}\left(\log \frac{a_{L i j}+a_{M i j}+a_{U i j}}{3}-\log \frac{w_{L i}+w_{M i}+w_{U i}}{3}+\log \frac{w_{L j}+w_{M j}+w_{U j}}{3}\right)^{2} .
$$

The comparison is sufficiently consistent when $C \mathrm{Cl}<0.35$ for $n=4$, and $C \mathrm{Cl}<0.37$ for $n>4$ [27]. 
For ranking the potential causes of human error during the maintenance of mining machines, the hierarchy shown in Figure 3 is used:

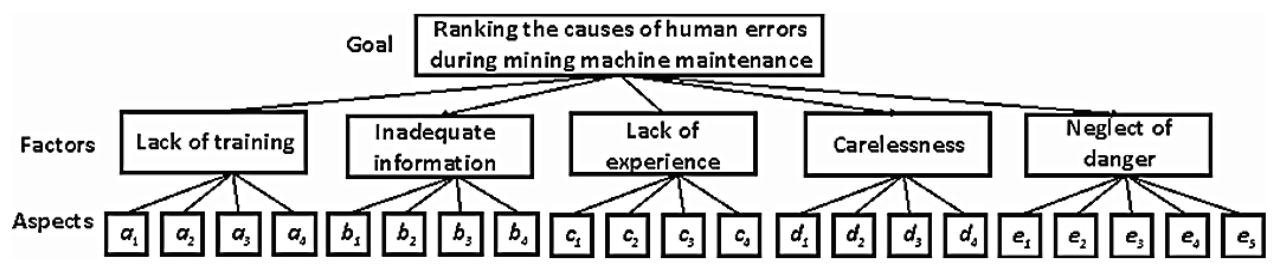

Figure 3: Hierarchical scheme for ranking the key causes of human error during mining machine maintenance

The hierarchy has three levels. The goal is to rank the causes of human error during the maintenance of mining machines. The level below defines the five main factors: lack of training, inadequate information, lack of experience, carelessness, and neglect of danger. The third level defines the key aspects. The factors and the key aspects, as well as their symbols, are presented in Table 2 . The list contains 21 aspects, classified according to five factors.

The following experts took part in a group decision-making process based on fuzzy AHP: a maintenance engineer, a technologist, an ergonomist, a psychologist, and an organisational scientist. They all had equal influence over the final decision. The individual fuzzy judgement matrices of the experts are presented in Table 4. Based on these results, the aggregated fuzzy judgement matrix is obtained (Table 5 ). The matrix is consistent because $C \mathrm{Cl}<0.35$. The mean aggregated weight (MAW) for the criteria is obtained.

Table 4: The individual fuzzy judgement matrix for the criteria

\begin{tabular}{|c|c|c|c|c|c|c|}
\hline $\mathrm{DM}_{1}$ & & $a$ & $b$ & $C$ & $d$ & $e$ \\
\hline \multirow{11}{*}{$\mathrm{DM}_{2}$} & $a$ & $(1,1,1)$ & $(1,2,3)$ & $(3,4,5)$ & $(3,5,7)$ & $(1 / 3,1,1)$ \\
\hline & $b$ & $(1 / 3,1 / 2,1)$ & $(1,1,1)$ & $(1,2,3)$ & $(1,3,5)$ & $(1 / 3,1 / 2,1)$ \\
\hline & c & $(1 / 5,1 / 4,1 / 3)$ & $(1 / 3,1 / 2,1)$ & $(1,1,1)$ & $(1,1,3)$ & $(1 / 5,1 / 4,1 / 3)$ \\
\hline & $d$ & $(1 / 7,1 / 5,1 / 3)$ & $(1 / 5,1 / 3,1)$ & $(1 / 3,1,1)$ & $(1,1,1)$ & $(1 / 7,1 / 5,1 / 3)$ \\
\hline & $e$ & $(1,1,3)$ & $(1,2,3)$ & $(3,4,5)$ & $(3,5,7)$ & $(1,1,1)$ \\
\hline & & a & $b$ & C & $d$ & $e$ \\
\hline & $a$ & $(1,1,1)$ & $(1,2,3)$ & $(1,2,3)$ & $(1,3,5)$ & $(1 / 3,1 / 2,1)$ \\
\hline & $b$ & $(1 / 3,1 / 2,1)$ & $(1,1,1)$ & $(1 / 3,1,1)$ & $(1 / 3,1 / 2,1)$ & $(1 / 5,1 / 3,1)$ \\
\hline & c & $(1 / 3,1 / 2,1)$ & $(1,1,3)$ & $(1,1,1)$ & $(1 / 3,1,1)$ & $(1 / 7,1 / 5,1 / 3)$ \\
\hline & $d$ & $(1 / 5,1 / 3,1)$ & $(1,2,3)$ & $(1,1,3)$ & $(1,1,1)$ & $(1 / 7,1 / 6,1 / 5)$ \\
\hline & $e$ & $(1,2,3)$ & $(1,3,5)$ & $(3,5,7)$ & $(5,6,7)$ & $(1,1,1)$ \\
\hline \multirow[t]{6}{*}{$\mathrm{DM}_{3}$} & & $a$ & $b$ & $c$ & $d$ & $e$ \\
\hline & $a$ & $(1,1,1)$ & $(2,3,4)$ & $(1,2,3)$ & $(1,3,5)$ & $(1,1,3)$ \\
\hline & $b$ & $(1 / 3,1 / 2,1)$ & $(1,1,1)$ & $(1,1,3)$ & $(1,2,3)$ & $(1 / 3,1 / 2,1)$ \\
\hline & c & $(1 / 3,1 / 2,1)$ & $(1 / 3,1,1)$ & $(1,1,1)$ & $(1,2,3)$ & $(1 / 3,1 / 2,1)$ \\
\hline & $d$ & $(1 / 5,1 / 3,1)$ & $(1 / 3,1 / 2,1)$ & $(1 / 3,1 / 2,1)$ & $(1,1,1)$ & $(1 / 5,1 / 3,1)$ \\
\hline & $e$ & $(1 / 3,1,1)$ & $(1,2,3)$ & $(1,2,3)$ & $(1,3,5)$ & $(1,1,1)$ \\
\hline \multirow[t]{6}{*}{$\mathrm{DM}_{4}$} & & a & $b$ & $c$ & $d$ & $e$ \\
\hline & $a$ & $(1,1,1)$ & $(1,2,3)$ & $(1,3,5)$ & $(3,4,5)$ & $(1 / 3,1 / 2,1)$ \\
\hline & $b$ & $(1 / 3,1 / 2,1)$ & $(1,1,1)$ & $(1,2,3)$ & $(1,2,3)$ & $(1 / 5,1 / 4,1 / 3)$ \\
\hline & c & $(1 / 5,1 / 3,1)$ & $(1 / 3,1 / 2,1)$ & $(1,1,1)$ & $(1,1,3)$ & $(1 / 5,1 / 3,1)$ \\
\hline & $d$ & $(1 / 5,1 / 3,1)$ & $(1 / 3,1 / 2,1)$ & $(1 / 3,1,1)$ & $(1,1,1)$ & $(1 / 7,1 / 5,1 / 3)$ \\
\hline & $e$ & $(1,2,3)$ & $(3,4,5)$ & $(1,3,5)$ & $(3,5,7)$ & $(1,1,1)$ \\
\hline \multirow[t]{6}{*}{$\mathrm{DM}_{5}$} & & $a$ & $b$ & $c$ & $d$ & $e$ \\
\hline & $a$ & $(1,1,1)$ & $(1,2,3)$ & $(1,2,3)$ & $(1,2,3)$ & $(1,3,5)$ \\
\hline & $b$ & $(1 / 3,1 / 2,1)$ & $(1,1,1)$ & $(1,1,3)$ & $(1,1,3)$ & $(1,2,3)$ \\
\hline & c & $(1 / 3,1 / 2,1)$ & $(1 / 3,1,1)$ & $(1,1,1)$ & $(1 / 3,1,1)$ & $(1,1,3)$ \\
\hline & $d$ & $(1 / 3,1 / 2,1)$ & $(1 / 3,1,1)$ & $(1,1,3)$ & $(1,1,1)$ & $(1,2,3)$ \\
\hline & $e$ & $(1 / 5,1 / 3,1)$ & $(1 / 3,1 / 2,1)$ & $(1 / 3,1,1)$ & $(1 / 3,1 / 2,1)$ & $(1,1,1)$ \\
\hline
\end{tabular}


Table 5: The aggregated fuzzy judgement matrix for the criteria

\begin{tabular}{lllllll}
\hline & $a$ & $b$ & $c$ & $d$ & $e$ & $M A W$ \\
\hline$a$ & $(1,1,1)$ & $(1.15,2.17,3.18)$ & $(1.25,2.49,3.68)$ & $(1.55,3.25,4.83)$ & $(0.52,0.94,1.72)$ & 0.28 \\
$b$ & $(0.33,0.50,1)$ & $(1,1,1)$ & $(0.80,1.32,2.41)$ & $(0.80,1.43,2.67)$ & $(0.34,0.53,1.00)$ & 0.17 \\
$c$ & $(0.27,0.40,0.80)$ & $(0.42,0.76,1.25)$ & $(1,1,1)$ & $(0.64,1.15,1.93)$ & $(0.29,0.38,0.80)$ & 0.14 \\
$d$ & $(0.21,0.31,0.64)$ & $(0.37,0.70,1.25)$ & $(0.52,0.87,1.55)$ & $(1,1,1)$ & $(0.23,0.34,0.58)$ & 0.12 \\
$e$ & $(0.58,1.06,1.93)$ & $(1,1.89,2.95)$ & $(1.25,2.61,3.50)$ & $(1.72,2.95,4.43)$ & $(1,1,1)$ & 0.29 \\
& $C C l=0.14$ & & & & & \\
\hline
\end{tabular}

According to the results presented in Table 5, the experts identified the operators' 'neglect of danger' $(e)$ and 'lack of training' $(a)$ as the major causes of errors during the maintenance of mining machines.

The same procedure is applied in the comparison of aspects. The comparison of aspects with respect to the lack of training is presented in Table 6. The aggregated fuzzy judgement matrix, based on the comparison of aspects in relation to the lack of training (criterion $a$ ), is presented in Table 7. As the most important aspects in this group, experts selected the poor training curricula (criterion $a_{1}$ ) and poor organisation of the training process (criterion $a_{4}$ ).

Table 6: The individual fuzzy judgement matrix for indicators, in relation to 'the lack of training' (criterion $a$ )

\begin{tabular}{|c|c|c|c|c|c|}
\hline $\mathrm{DM}_{1}$ & & $a_{1}$ & $a_{2}$ & $a_{3}$ & $a_{4}$ \\
\hline & $a_{1}$ & $(1,1,1)$ & $(1,2,3)$ & $(1,3,5)$ & $(1,1,3)$ \\
\hline & $a_{2}$ & $(1 / 3,1 / 2,1)$ & $(1,1,1)$ & $(1,1,3)$ & $(1 / 3,1 / 2,1)$ \\
\hline & $a_{3}$ & $(1 / 5,1 / 3,1)$ & $(1 / 3,1,1)$ & $(1,1,1)$ & $(1 / 4,1 / 3,1 / 2)$ \\
\hline & $a_{4}$ & $(1 / 3,1,1)$ & $(1,2,3)$ & $(2,3,4)$ & $(1,1,1)$ \\
\hline \multirow[t]{5}{*}{$\mathrm{DM}_{2}$} & & $a_{1}$ & $a_{2}$ & $a_{3}$ & $a_{4}$ \\
\hline & $a_{1}$ & $(1,1,1)$ & $(1,3,5)$ & $(1,2,3)$ & $(1 / 3,1,1)$ \\
\hline & $a_{2}$ & $(1 / 5,1 / 3,1)$ & $(1,1,1)$ & $(1 / 3,1 / 2,1)$ & $(1 / 5,1 / 3,1)$ \\
\hline & $a_{3}$ & $(1 / 3,1 / 2,1)$ & $(1,2,3)$ & $(1,1,1)$ & $(1 / 3,1 / 2,1)$ \\
\hline & $a_{4}$ & $(1,1,3)$ & $(1,3,5)$ & $(1,2,3)$ & $(1,1,1)$ \\
\hline \multirow[t]{5}{*}{$\mathrm{DM}_{3}$} & & $a_{1}$ & $a_{2}$ & $a_{3}$ & $a_{4}$ \\
\hline & $a_{1}$ & $(1,1,1)$ & $(1,2,3)$ & $(3,4,5)$ & $(1 / 3,1 / 2,1)$ \\
\hline & $a_{2}$ & $(1 / 3,1 / 2,1)$ & $(1,1,1)$ & $(1,2,3)$ & $(1 / 5,1 / 3,1)$ \\
\hline & $a_{3}$ & $(1 / 5,1 / 4,1 / 3)$ & $(1 / 3,1 / 2,1)$ & $(1,1,1)$ & $(1 / 9,1 / 7,1 / 7)$ \\
\hline & $a_{4}$ & $(1,2,3)$ & $(3,4,5)$ & $(7,7,9)$ & $(1,1,1)$ \\
\hline \multirow[t]{5}{*}{$\mathrm{DM}_{4}$} & & $a_{1}$ & $a_{2}$ & $a_{3}$ & $a_{4}$ \\
\hline & $a_{1}$ & $(1,1,1)$ & $(1,3,5)$ & $(3,4,5)$ & $(1 / 3,1,1)$ \\
\hline & $a_{2}$ & $(1 / 5,1 / 3,1)$ & $(1,1,1)$ & $(1,2,3)$ & $(1 / 5,1 / 3,1)$ \\
\hline & $a_{3}$ & $(1 / 5,1 / 3,1)$ & $(1 / 3,1 / 2,1)$ & $(1,1,1)$ & $(1 / 5,1 / 4,1 / 3)$ \\
\hline & $a_{4}$ & $(1,1,3)$ & $(1,3,5)$ & $(3,4,5)$ & $(1,1,1)$ \\
\hline \multirow[t]{5}{*}{$\mathrm{DM}_{5}$} & & $a_{1}$ & $a_{2}$ & $a_{3}$ & $a_{4}$ \\
\hline & $a_{1}$ & $(1,1,1)$ & $(1,2,3)$ & $(1,1,3)$ & $(1,2,3)$ \\
\hline & $a_{2}$ & $(1 / 3,1,1)$ & $(1,1,1)$ & $(1 / 3,1 / 2,1)$ & $(1,1,3)$ \\
\hline & $a_{3}$ & $(1 / 3,1,1)$ & $(1,2,3)$ & $(1,1,1)$ & $(1,2,3)$ \\
\hline & $a_{4}$ & $(1 / 3,1 / 2,1)$ & $(1 / 3,1,1)$ & $(1 / 3,1 / 2,1)$ & $(1,1,1)$ \\
\hline
\end{tabular}

Table 7: The aggregated fuzzy judgement matrix for indicators, in relation to the lack of training' (criterion $a$ )

\begin{tabular}{llllll}
\hline & $a_{1}$ & $a_{2}$ & $a_{3}$ & $a_{4}$ & $M A W$ \\
\hline$a_{1}$ & $(1,1,1)$ & $(1,2.35,3.68)$ & $(1.55,2.49,4.08)$ & $(0.52,1,1.55)$ & 0.34 \\
$a_{2}$ & $(0.27,0.43,1)$ & $(1,1,1)$ & $(0.64,1,1.93)$ & $(0.31,0.43,1)$ & 0.17 \\
$a_{3}$ & $(0.25,0.40,0.64)$ & $(0.52,1,1.55)$ & $(1,1,1)$ & $(0.28,0.41,0.59)$ & 0.14 \\
$a_{4}$ & $(0.64,1.00,1.93)$ & $(1,2.35,3.27)$ & $(1.70,2.43,3.52)$ & $(1,1,1)$ & 0.34 \\
& $C C l=0.01$ & & & & \\
\hline
\end{tabular}

The aggregated fuzzy judgement matrices, based on the comparison of aspects in relation to the other criteria, are presented in Tables 8-11. 
Table 8: The aggregated fuzzy judgement matrix for indicators, in relation to 'inadequate information' (criterion b)

\begin{tabular}{llllll}
\hline & $b_{1}$ & $b_{2}$ & $b_{3}$ & $b_{4}$ & MAW \\
\hline$b_{1}$ & $(1,1,1)$ & $(0.80,1,2.41)$ & $(0.24,0.32,0.63)$ & $(0.28,0.55,0.80)$ & 0.15 \\
$b_{2}$ & $(0.42,1,1.25)$ & $(1,1,1)$ & $(0.22,0.32,0.46)$ & $(0.29,0.51,0.76)$ & 0.13 \\
$b_{3}$ & $(1.58,3.16,4.17)$ & $(2.19,3.16,4.46)$ & $(1,1,1)$ & $(0.92,2.22,3.13)$ & 0.44 \\
$b_{4}$ & $(1.25,1.82,3.55)$ & $(1,32,1.97,3.39)$ & $(0.32,0.45,1.08)$ & $(1,1,1)$ & 0.28 \\
& $C C l=0.02$ & & & & \\
\hline
\end{tabular}

Table 9: The aggregated fuzzy judgement matrix for indicators, in relation to 'the lack of experience' (criterion $c$ )

\begin{tabular}{llllll}
\hline & $c_{1}$ & $c_{2}$ & $c_{3}$ & $c_{4}$ & $M A W$ \\
\hline$c_{1}$ & $(1,1,1)$ & $(0.17,0.29,0.47)$ & $(0.80,1.64,2.67)$ & $(1,1.64,3.32)$ & 0.20 \\
$c_{2}$ & $(2.14,2.50,5.81)$ & $(1,1,1)$ & $(3,4.14,5.24)$ & $(2.81,4.66,5.52)$ & 0.55 \\
$c_{3}$ & $(0.37,0.61,1.25)$ & $(0.19,0.24,0.33)$ & $(1,1,1)$ & $(0.37,0.61,1.25)$ & 0.12 \\
$c_{4}$ & $(0.30,0.61,1)$ & $(0.18,0.21,0.36)$ & $(0.8,1.64,2.67)$ & $(1,1,1)$ & 0.14 \\
& $C C l=0.01$ & & & & \\
\hline
\end{tabular}

Table 10: The aggregated fuzzy judgement matrix for indicators, in relation to 'inattention' (criterion $d$ )

\begin{tabular}{llllll}
\hline & $\boldsymbol{d}_{1}$ & $\boldsymbol{d}_{2}$ & $\boldsymbol{d}_{3}$ & $\boldsymbol{d}_{4}$ & MAW \\
\hline$d_{1}$ & $(1,1,1)$ & $(0.80,1.25,2.67)$ & $(0.64,1.15,1.93)$ & $(0.23,0.33,0.54)$ & 0.19 \\
$d_{2}$ & $(0.37,0.80,1.25)$ & $(1,1,1)$ & $(0.39,0.80,1.08)$ & $(0.17,0.23,0.39)$ & 0.13 \\
$d_{3}$ & $(0.52,0.87,1.55)$ & $(0.92,1.25,2.55)$ & $(1,1,1)$ & $(0.21,0.31,0.49)$ & 0.17 \\
$d_{4}$ & $(1.84,3.06,4.36)$ & $(2.54,4.28,5.81)$ & $(2.04,3.25,4.66)$ & $(1,1,1)$ & 0.51 \\
& $C C l=0.01$ & & & & \\
\hline
\end{tabular}

Table 11: The aggregated fuzzy judgement matrix for indicators, in relation to 'neglect of danger' (criterion $e$ )

\begin{tabular}{lllllll}
\hline & $e_{1}$ & $e_{2}$ & $e_{3}$ & $e_{4}$ & $e_{5}$ & $M A W$ \\
\hline$e_{1}(1,1,1)$ & $(0.30,0.46,1)$ & $(0.80,1,2.41)$ & $(0.80,1.78,2.95)$ & $(0.15,1.89,2.95)$ & 0.21 \\
$e_{2}$ & $(1,2.17,3.32)$ & $(1,1,1)$ & $(1,2.05,3.68)$ & $(2.41,3.81,4.83)$ & $(2.77,4.07,5.30)$ & 0.38 \\
$e_{3}$ & $(0.42,1,1.25)$ & $(0.27,0.49,1)$ & $(1,1,1)$ & $(1,1.89,2.95)$ & $(1.25,2.00,2.95)$ & 0.19 \\
$e_{4}$ & $(0.34,0.56,1.25)$ & $(0.21,0.26,0.42)$ & $(0.34,0.53,1)$ & $(1,1,1)$ & $(0.80,1,2.41)$ & 0.12 \\
$e_{5}(0.34,0.53,0.87)$ & $(0.19,0.25,0.36)$ & $(0.34,0.50,0.80)$ & $(0.42,1,1.25)$ & $(1,1,1)$ & 0.10 \\
& $C C l=0.01$ & & & & &
\end{tabular}

The final results are presented in Table 12. Inadequate diagnostic equipment is the most important in relation to 'inadequate information received', as it connects the emergency situations and the operators' ability to identify the potential cause of an accident. In relation to 'lack of experience', the insufficient years of service are identified as the most important. Personal characteristics and poor working conditions are identified as the most important aspects in relation to 'inattention', while lack of understanding of the work process, poor organisation of the workplace, and the failure to follow technical maintenance instructions are the most important aspects in relation to the 'neglect of danger' criterion.

Based on the results of the group fuzzy AHP analysis presented here, we can conclude the following: human error in the case study during the maintenance of mining machines was primarily caused by ignoring the hazards (factor $e$ ), and lack of training (factor $a$ ). The factors 'inadequate information' (factor $b$ ), 'lack of experience' (factor $c$ ), and 'inattention' (factor d) were much less important (Table 5).

In relation to 'lack of training', poor organisation of the training (aspect $a_{4}$ ) and poor training curricula (aspect $a_{1}$ ) were dominant (Table 7). The 'inadequate diagnostic equipment' aspect $\left(b_{3}\right)$ was dominant in relation to the 'inadequate information' criterion (Table 8). The 'insufficient years of service' aspect $\left(c_{2}\right)$ was dominant in relation to the 'lack of experience' criterion (Table 9). 'Personal characteristics' $\left(d_{4}\right)$ were dominant in relation to the 'inattention' factor. In relation to the 'neglect of danger' factor, 'failure to follow technical maintenance instructions' $\left(e_{2}\right)$, 'poor organisation of the workplace' $\left(e_{1}\right)$, and 'lack of understanding of the work process' $\left(e_{3}\right)$ were dominant (Table 10). 
Table 12: The ranking of the aspects influencing human error during the maintenance of mining machines

\begin{tabular}{|c|c|c|c|c|c|c|c|c|}
\hline & Aspect & $\begin{array}{l}a \\
0.28\end{array}$ & $\begin{array}{l}b \\
0.17\end{array}$ & $\begin{array}{l}c \\
0.14\end{array}$ & $\begin{array}{l}d \\
0.12\end{array}$ & $\begin{array}{l}e \\
0.29\end{array}$ & $\begin{array}{l}\text { Indicator } \\
\text { priority } \\
\text { weight }\end{array}$ & Rank \\
\hline$a_{1}$ & Poor training curricula & 0.34 & & & & & 0.096 & 3 \\
\hline$a_{2}$ & Inadequate trainers & 0.17 & & & & & 0.048 & 9 \\
\hline$a_{3}$ & $\begin{array}{l}\text { Personal characteristics of the } \\
\text { trainees }\end{array}$ & 0.14 & & & & & 0.039 & 11 \\
\hline$a_{4}$ & $\begin{array}{l}\text { Poor organisation of the training } \\
\text { process }\end{array}$ & 0.34 & & & & & 0.096 & 2 \\
\hline$b_{1}$ & Lack of guidelines & & 0.15 & & & & 0.026 & 15 \\
\hline$b_{2}$ & Incomplete guidelines & & 0.13 & & & & 0.022 & 17 \\
\hline$b_{3}$ & Inadequate diagnostic equipment & & 0.44 & & & & 0.074 & 5 \\
\hline$b_{4}$ & Ambiguous guidelines & & 0.28 & & & & 0.047 & 10 \\
\hline$c_{1}$ & Inadequate previous experience & & & 0.20 & & & 0.027 & 14 \\
\hline$c_{2}$ & Insufficient years of service & & & 0.55 & & & 0.075 & 4 \\
\hline$c_{3}$ & $\begin{array}{l}\text { Application of inappropriate } \\
\text { devices }\end{array}$ & & & 0.12 & & & 0.016 & 20 \\
\hline$c_{4}$ & $\begin{array}{l}\text { Low quality of commissioning and } \\
\text { adjustment activities }\end{array}$ & & & 0.14 & & & 0.019 & 19 \\
\hline$d_{1}$ & Poor working conditions & & & & 0.19 & & 0.023 & 16 \\
\hline$d_{2}$ & Living conditions & & & & 0.13 & & 0.016 & 21 \\
\hline$d_{3}$ & Low motivation & & & & 0.17 & & 0.021 & 18 \\
\hline$d_{4}$ & Personal characteristics & & & & 0.51 & & 0.064 & 6 \\
\hline$e_{1}$ & Poor organisation of the workplace & & & & & 0.21 & 0.060 & 7 \\
\hline$e_{2}$ & $\begin{array}{l}\text { Failure to follow technical } \\
\text { maintenance instructions }\end{array}$ & & & & & 0.38 & 0.111 & 1 \\
\hline$e_{3}$ & $\begin{array}{l}\text { Lack of understanding of the work } \\
\text { process }\end{array}$ & & & & & 0.19 & 0.055 & 8 \\
\hline$e_{4}$ & Personal characteristics - riskiness & & & & & 0.12 & 0.034 & 12 \\
\hline$e_{5}$ & $\begin{array}{l}\text { Inadequate instructions on work } \\
\text { hazards }\end{array}$ & & & & & 0.10 & 0.028 & 13 \\
\hline
\end{tabular}

Regarding the final aspect priorities, the following were the most important: failure to follow technical maintenance instructions; poor organisation of the training process; poor training curricula; insufficient years of service; inadequate diagnostic equipment; personal characteristics; poor organisation of the workplace; and lack of understanding of the work process.

The aspects are used to identify the key indicators of maintenance efficiency. Based on them, the set of 70 indicators is defined [23]. These indicators are used for further description of the maintenance improvement strategy.

\section{CONCLUSION}

Factors and aspects describing specific effects and results of mining machine maintenance are important for identifying potential causes of human error during maintenance. The results of the analysis of the key aspects are the foundation for efficient decision-making during the maintenance of mining machines.

The two-phase method presented here is used to identify the key aspects that can cause human error during maintenance. The procedure for ranking the key aspects is based on the group fuzzy AHP method. The consistency check proved that the individual assessments are consistent. During the additional session, the experts analysed the obtained results and accepted them.

The most important aspects are related to work instructions and organisation, individual training and characteristics, work experience, and available equipment. According to the results of the analysis, efficient maintenance can be achieved by more efficient organisation of the maintenance procedures, better monitoring of equipment, and improved instructions on the maintenance of mining machines and working procedures. Continuous monitoring of the indicators describing these 
aspects can improve maintenance in a complex coal mine system, and increase the efficiency of its production.

\section{REFERENCES}

[1] Dhillon, B.S. \& Liu, Y. 2006. Human error in maintenance: A review. Journal of Quality in Maintenance Engineering, 12(1), pp. 21-36.

[2] Hoseinie, S.H., Ghodrati, B. \& Kumar, U. 2014. Cost-effective maintenance scheduling of cutting arms of drum shearer machine. International Journal of Mining, Reclamation and Environment, 28(5), pp. 297 310.

[3] Wang, W. \& Wu, S. 2014. An inspection model subject to small stoppages and hard failures. Quality Technology and Quantitative Management, 11(3), pp. 255-264.

[4] Dhillon, B.S. 2008. Mining equipment reliability, maintainability, and safety. New York, USA: SpringerVerlag.

[5] Horbery, T.J., Burgess-Limerick, R. \& Steiner, L.J. 2011. Human factors for the design, operation, and maintenance of mining equipment. Boca Raton, USA: CRC Press, Taylor \& Francis Group.

[6] Papic, L., Kovacevic, S., Galar, D. \& Thaduri, A. 2015. Investigation of causes of mining machines maintenance problems. In: Kumar, U., Ahmadi, A., Verma, A.K. \& Varde, P. (eds) Current trends in reliability, availability, maintainability and safety. Part of the series 'Lecture Notes in Mechanical Engineering', Springer Verlag, pp. 283-299.

[7] Cooper, D. 2003. Psychology, risk and safety: Understanding how personality and perception can influence risk taking. Professional Safety, 48, pp. 39-46.

[8] Mason, S. 1996. Measuring attitudes to improve electricians' safety. Mining Technology, 78, pp. 166-170.

[9] Gordon, S.E. 1994. Systematic training program design: Maximizing effectiveness and minimizing liability. Englewood Cliffs, NJ, USA: Prentice Hall.

[10] Spiegel, S.J. \& Veiga, M.M. 2005. Building capacity in small-scale mining communities: Health, ecosystem sustainability, and the Global Mercury Project. EcoHealth, 2, pp. 361-369.

[11] Motsoeneng, D., Schultz, C. \& Bezuidenhout, A. 2015. Validation of training priorities of engineers in the platinum mining industry in South Africa. South African Journal of Industrial Engineering, 26(3), pp. 1-11.

[12] Laurence, D. 2005. Safety rules and regulations on mine sites - The problem and a solution. Journal of Safety Research, 36(1), pp. 39-50.

[13] Van Niekerk, A.J. \& Visser, J.K. 2010. The role of relationship management in the successful outsourcing of maintenance. South African Journal of Industrial Engineering, 21(2), pp. 79-90.

[14] Donoghue, A.M. 2004. Heat illness in the US mining industry. American Journal of Industrial Medicine, 45(1), pp. 351-356.

[15] Van den Honert, A.F. \& Vlok, P.J. 2015. Estimating the continuous risk of accidents occurring in the mining industry in South Africa. South African Journal of Industrial Engineering, 26(3), pp. 71-85.

[16] Cliff, D. \& Horberry, T. 2008. Hours of work risk factors for coal mining. International Journal of Mining and Mineral Engineering, 1(1), pp. 74-94.

[17] Mason S. \& Rushworth, A.M. 1991. Improving mining machinery maintainability. London, UK: Sterling Publications for the British Coal Corporation.

[18] Morgan, C.B. 1998. Implementing training programs - Operation, maintenance and safety. Proceedings of 30th IEEE Cement Industry Technical Conference, Quebec, Canada, pp. 233-247.

[19] Bulut, E., Duru, O., Keçeci, T. \& Yoshidaa, S. 2012. Use of consistency index, expert prioritization and direct numerical inputs for generic fuzzy-AHP modeling: A process model for shipping asset management. Expert Systems with Applications, 39(2), pp. 1911-1923.

[20] Ishikawa, K. 1985. What is total quality control? The Japanese way. New Jersey, USA: Prentice Hall Inc.

[21] Reason, J. 1990. Human error. Cambridge, UK: Cambridge University Press.

[22] Tague, N.R. 2005. The quality toolbox. Milwaukee, USA: ASQ Quality Press.

[23] Kovacevic, S. 2015. Investigation of integration management system influence degree on mining machines specific maintenance operations risk decreasing. PhD Thesis submitted to the Department of Industrial and Systems Engineering, Faculty of Technical Sciences, Cacak, University of Kragujevac, Serbia (in Serbian).

[24] Janackovic, G., Savic, S. \& Stankovic, M. 2013. Selection and ranking of occupational safety indicators based on fuzzy AHP: Case study in road construction companies. South African Journal of Industrial Engineering, 24(3), pp. 175-189.

[25] Zadeh, L.A. 1965. Fuzzy sets. Information and Control, 8(3), pp. 338-353.

[26] Crawford, G. \& Williams, C. 1985. A note on the analysis of subjective judgment matrices. Journal of Mathematical Psychology, 29(4), pp. 387-405.

[27] Aguarón J. \& Moreno-Jiménez, J.M. 2003. The geometric consistency index: Approximated thresholds. European Journal Operational Research, 147(1), pp. 137-145. 